\title{
Efsiensi Kinerja Rantai Pasok Gula Semut CV. Menoreh Politan Di Kabupaten Kulon Progo \\ (Efficiency of CV Menoreh Politan Supply Chain Performance Of Coconut Sugar , Kulon Progo Regency)
}

\author{
Annisa Fajar Fadhilah ${ }^{1)}$, Rita Nurmalina ${ }^{2)}$, dan Netti Tinaprilla ${ }^{2)}$ \\ 1) Program Studi Magister Sains Agribisnis, Departemen Agribisnis, Fakultas Ekonomi \\ dan Manajemen, Institut Pertanian Bogor \\ 2) Departemen Agribisnis, Fakultas Ekonomi dan Manajemen, Institut Pertanian Bogor \\ e-mail: fajarannisa2@gmail.com
}

\begin{abstract}
CV Menoreh Politan is one of sugar coconut companies in Kalibuko, Kokap, Kulon Progo Regency Yogyakarta. Some of its coconut sugar products are sent to various regions in Indonesia, and some others are occasionally exported. The company, however, had encountered some constraints both in supply and product fulfillment. This research was, therefore, aimed at studying the efficiency of performance at $C V$ Menoreh Politan. The input variables used were order fulfillment cycle, supply chain flexibility, total supply chain cost, cash to cash cycle time, and daily inventory, while input variables for output of supply chain performance were delivery performance, order fulfillment, and conformity with standard. The efficiency of coconut sugar supply chain performance is analyzed by Data Envelopment Analysis (DEA) method with constant return to scale (CRS) assumption. Analysis of farmer efficiency by using Data Envelopment Analysis (DEA) resulted in farmer efficiency level. CV Menoreh Politan has operated efficiently with its 14 partners (24.14 percent), while the remaining 44 farmers of CV Menoreh Politan (75.86 percent) have not reached the maximum efficiency level. The inefficiency of farmers was largely due to the cost of supply chains and long-term enterprise turnover. Overall, the collectors have been fully operational. Similarly, the company has been technically efficient, meaning that in terms of input and output, it has been good.
\end{abstract}

Keywords: coconut sugar, FSCN, SCOR, supply chain.

\section{Pendahuluan}

CV Menoreh Politan adalah perusahaan gula semut yang terletak di Dusun Kalibuko, Kokap, Kabupaten Kulon Progo Yogyakarta. Produk gula semut diolah berdasarkan standar internasional. Perusahaan ini sudah mendapatkan sertifikat Belanda (Control Union) yang terkait dengan standar keamanan produk gula semut. Fakta di lapangan menunjukkan perusahaan ini menemui beberapa kendala yaitu adanya keterbatasan bahan baku nira kelapa. Permintaan dari pihak konsumen selalu tinggi namun dalam pemenuhannya tidak sesuai dengan yang diharapkan (CV Menoreh Politan, 2016). 
Pengukuran efisiensi kinerja perusahaan ini dilakukan untuk mengevaluasi kinerja rantai pasok yang ada dan memperbaikinya sehinngga kinerja rantai pasok gula semut ini diharapkan dapat meningkat. Pengukuran kinerja didefinisikan sebagai proses untuk kuantifikasi efisiensi dan efektivitas dari suatu tindakan (Tangen, 2004).

Penilaian kinerja rantai pasok antara pemasok, perusahaan dan pelanggan yang baik dapat diukur dengan salah satu model pengu-kuran kinerja manajemen rantai pasok adalah model Supply Chain Operations Reference (SCOR), yaitu suatu model yang dirancang oleh Supply-Chain Council (SCC) (Bolstorff \& Rosenbaum, 2003).

Data Envelopment Analysis (DEA) adalah teknik berbasis program linier untuk mengukur efisiensi suatu unit organisasi yang disebut Decision Making Units (DMU) dalam menggunakan sumber daya yang tersedia untuk mengha-silkan suatu output tertentu (Tanjung \& Devi, 2013).

Tujuan penelitian adalah bertujuan mengetahui efisiensi petani, pengepul dan perusahaan pada rantai pasok gula semut CV Menoreh Politan pada bulan April 2017, menganalisis variabel yang paling berpengaruh terhadap nilai efisiensi, serta mengevaluasi nilai target hasil potential improvement yang harus dipertahankan masing-masing variabel input.

\section{Metode}

Penelitian dilakukan di CV Menoreh Politan di Desa Kalirejo, Kecamatan Kokap Kabuaten Kulon Progo. Pemilihan lokasi penelitian dilakukan secara sengaja (purposive) dengan pertimbangan bahwa Kulon Progo merupakan salah satu daerah penghasil gula semut dan juga merupakan produk unggulan. Selain itu CV Menoreh Politan merupakan salah satu agroindustri produksi terbesar di Kulon Progo (Disperindag Kulon Progo 2016). Penelitian dilksanakan bulan April 2017.

Jenis data yang digunakan pada penelitian ini adalah data primer yang diperoleh dari wawancara, sedangkan data sekunder diperoleh melalui literatur terkait, lembaga pemerintah yang mendukung penelitian. Responden pada penelitian ini adalah 58 resonden petani mitra, 8 pengepul dan Perusahaan CV Menoreh Politan.

Analisis Rantai Pasok Gula Semut dilaku

Variabel input dan output yang digunakan didasarkan pada hasil perancangan model kinerja dengan mengadaptasi model SCOR. Variabel input yang digunakan seperti metrik siklus waktu pemenuhan pesanan, fleksibilitas rantai pasok, biaya SCM, cash to cash cycle time, persediaan harian. Sementara variabel output terdiri dari metrik kinerja pengiriman, pemenuhan pesanan dan kesesuaian dengan standart mutu. Selanjutnya data mengenai input dan output diolah dengan metode DEA. Hasil pengolahan dengan menggunakan DEA akan diperoleh kinerja rantai pasok gula semut sebagai bahan evaluasi untuk meningkatkan kinerja. Kinerja DMU yang efisien dibandingkan dengan kinerja DMU lainnya.

Variabel input yang digunakan merupakan sumberdaya yang dipergunakan untuk melakukan fungsi ranstai pasok. Variabel output adalah hasil yang merupakan perwujudan dari aktivitas rantai pasok yang telah dilakukan. Variabel input dan output yang digunakan untuk mengevaluasi kinerja para pelaku rantai pasok dengan menggunakan pendekatan DEA dapat dilihat pada gambar berikut. 


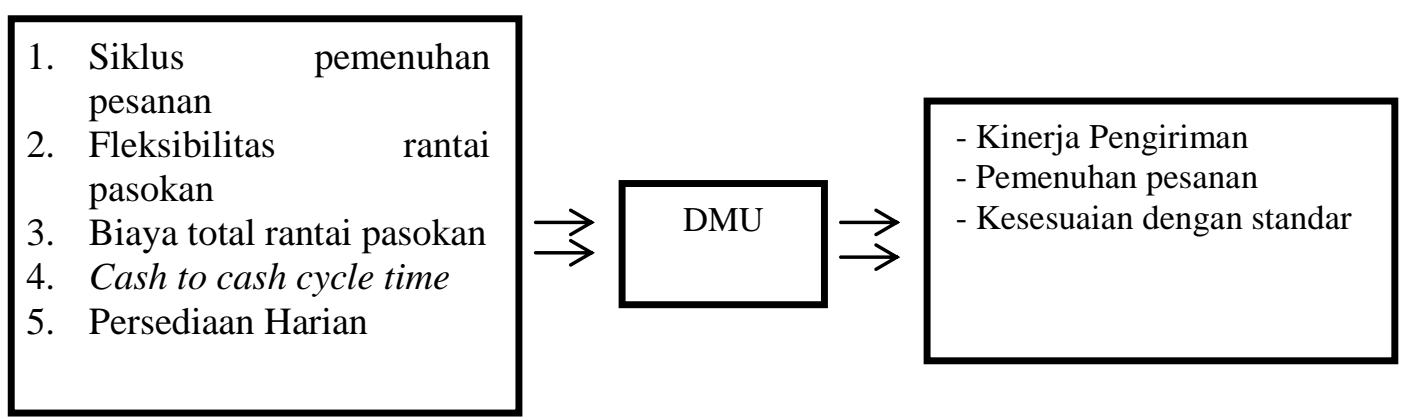

Gambar 1 Alur cara kerja pengolahan data pada DEA

Sumber : Setiawan (2011)

Model dasar dari Data Envelopment Analysis adalah sebagai berikut:

Efisiensi maksimum :

$\mu s 1=\frac{\sum r V_{r Y}{ }_{r j s 1}}{\sum V_{i X i j s 1}}$.

Error! Reference source not found. = Efisiensi maksium

$\mathrm{r} \quad=$ variabel output

$\mathrm{i} \quad=$ variabel input

$\mathrm{k}=$ Unit pengambil keputusan yang akan dievaluasi

$\mathrm{Ur} \quad=$ Bobot dari output

$\mathrm{Vi}=$ Bobot dari input

Yrk = Nilai output

Xik = Nilai input

(Zhang, Liu dan Li, 2002)

Adapun variabel yang diadapatasi oleh model SCOR digolongkan sebagai berikut:

1. Kinerja pengiriman adalah presentase pengiriman pesanan tepat waktu yang sesuai dengan tanggal pesanan konsumen dan atau tanggal yang diinginkan konsumen

2. Pemenuhan pesanan adalah presentase jumlah permintaan yang dipenuhi tanpa menunggu dan diukur setiap jenis produk

3. Kesesuaian dengan standart atau mutu

4. Waktu tunggu pemenuhan pesanan menerangkan waktu yang dibutuhkan oleh perusahaan untuk memenuhi permintaan konsumen mulai dari pemasok hingga ke tangan konsumen

5. Fleksibilitas rantai pasokan adalah waktu yang dibutuhkan untuk merespon rantai pasokan apabila ada pesanan yang tak terduga baikpeningkatan atau penurunan pesanan

6. Biaya total SCM adalah menerangkan total biaya yang dikeluarkan oleh perusahaan dalam melakukan penanganan bahan mulai dari pemasok sampai ke konsumen

7. Siklus cash to cash adalah perputaran uang perusahaan mulai dari pembayaran bahan baku ke pemasok sampai pembayaran atau pelunasan produk oleh konsumen

8. Persediaan harian adalah lamanya persediaan yang cukup untuk memenuhi kebutuhan jika tidaka ada pasokan lebih lanjut 


\section{HASIL DAN PEMBAHASAN}

\section{Efisiensi Kinerja Rantai Pasok Gula Semut di Kulon Progo}

Pengukuran kinerja manajemen rantai pasok digunakan untuk menentukan apa yang akan diukur dan dimonitor serta menciptakan kesesuaian antara kegiatan rantaipasok dengan matriks pengukuran. Efisiensi kinerja rantai pasok dianalisis dengan metode Data Envelopment Analysis (DEA) untuk mengetahui tingkat efisiensi rantai pasok gula semut di Kulon Progo. Sedangkan penelitian Saragih (2016) dan Herawati (2015) mengukur kinerja rantai pasok dengan mengggunakan pendekatan efisiensi pemasaran melalui pengukuran marjin pemasaran dan farmer's share. Pengukuran kinerja rantai pasok gula semut dilihat dari kinerja petani,pengepul dan perusahaan selama satu bulan produksi, yaitu Bulan April 2017. Berbeda dengan penelitian Sari (2015) dan Setiawan et al (2011) yang melihat kinerja rantai pasok selama dua semester yang juga menggunakan pendekatan DEA. Rantai pasok gula semut di ecamatan Kokap mengalirkan gula semut berkualitas baik yang sudah dalm bentuk kemasan.

Penelitian ini menganalisis efisiensi rantai pasok gula semut di Kecamatan Kokap dengan membandingkan kinerja petani gula semut, kinerja pengepul, dan jugaa kinerja rantai pasok gula semut pada tingkat perusahaan. Dengan demikian efisiensi kinerja rantai pasok gula semut dianalisis petani mitra CV Menoreh Politan, pengepul,serta membandingkan kinerja rantai pasok gula semut antara CV Menoreh Politan dengan nilai superior yang telah ditetapkan dalam foodSCOR card (Bolstroff 2011).

Pengukuran kinerja dilakukan untuk membandingkan unit entitas satu dengan lainnya. Bagi perusahaan, dengan pengukuran kinerja petani, dapat diketahui petani mitra mana saja yang harus ditingkatkan kinerjanya. Setiap atribut kinerja mempunyai indikator kinerja yang berguna untuk mengetahui efisiensi kinerja dari suatu organisasi. Atribut kinerja ini terdiri dari reliabilitas, responsibilitas, fleksibilitas, biaya dan aset, dan Sustiyana et al (2013) hanya menggunakan atribut fleksibilitas, aset, reliabilitas, responsibilitas dimana indikator cash to cash mempunyai bobot tertinggi yaitu senilai 0.299 dan menjadi prioritas utama. Alasan pemilihan indikator ini adalah semua anggota rantai pasok beracuan pada siklus pembayaran yang hasilnya akan digunakan untuk kegiatan perdagangan gula siwalan selanjutnya. Jika proses pembayaran tersendat, maka lembaga pemasaran tidak akan optimal atau bisa jadi akan terhenti dalam menyediakan gula siwalan bagi pembeli lain pada proses jual beli selanjutnya.

Pengukuran DEA berdasarkan input dan output yang dilakukan oleh petani, pengepul, dan perusahaan pada komoditas gula semut sama seperti peneitian Yolandika (2016). Variabel input adalah waktu tunggu pemenuhan, siklus pemenuhan pesanan, fleksibilitas rantai pasok, biaya total manajemen rantai pasok, siklus cash to cash, dan persediaan harian. Sedangkan, variabel output adalah kinerja pengiriman, pemenuhan pesanan, dan kesesuaian dengan standar.

Pengukuran kinerja dilakukan pada petani kelompok tani mitra perusahaan, pengepul dan perusahaan. Petani mitra tersebut memiliki kriteria petani yang melakukan pengolahan gula smeut secara terus menerus. Produksi masing-masing petani mitra bermacam-macam sesuai jumlah nira kelapa yang dideres. 
Pengukuran kinerja dilakukan selama satu bulan produksi gula semut yaitu Bulan Maret hingga April 2017. Pengukuran kinerja dilakukan pada petani gula semut di Kecamatan Kokap kabupaten Kulon Progo sebanyak 58 orang petani, 8 pengepul, dan perusahaan yang melakukan pengolahan gula semut di Kulon Progo. Petani gula semut di Kecamatan Kokap memiliki karakteristik yang berbeda-beda. Lahan yang digunakan petani untuk budidaya kelapa berlokasi di Kecamatan Kokap, tetapi pada daerah yang berbeda-beda. Petani mitra juga memiliki karakteristik yang berbeda-beda. Dari seluruh petani yang menjadi mitra sebagian besar yang menderes kelapa biasanya adalah laki-laki, dan yang mengolah nira kelapa menjadi gula semut biasanya adalah perempuan.

Data yang diolah merupakan data rata-rata dari masing-masing input dan output yang diperoleh satu bulan produksi gula semut, yaitu Bulan Maret hingga April. Setelah input dan output dimasukkan, data diolah untuk mendapatkan informasi petani gula semut mana yang memiliki kinerja rantai pasok yang efisien jika dibandingkan dengan petani lainnya. Rekapitulasi nilai input dan output pengukuran kinerja petani anggota kelompok tani dapat dilihat pada Lampiran 1.

Berdasarkan hasil perhitungan terhadap nilai input dan output kinerja rantai pasok gula semut di Kulon Progo, pada tingkat petani mitra dietahui bahwa sebagian besar efisiensi kinerja yang dimiliki belum mencapai $100 \%$. Perhitungan dilakukan dengan menggunakan software WDEA, didapatkan hasil bahwa dari 58 sampel petani mitra atau Decision Making Unit hanya 14 petani mitra yang telah memiliki efisiensi kinerja $100 \%$. Artinya kinerja 14 orang petani mitra tersebut telah efisien. Namun petani anggota kelompok tani lainnya masih belum memiliki kinerja rantai pasok yang efisien. Hasil perhitungan kinerja petani mitra perusahaan dapat dilihat pada Gambar 23 di bawah ini.

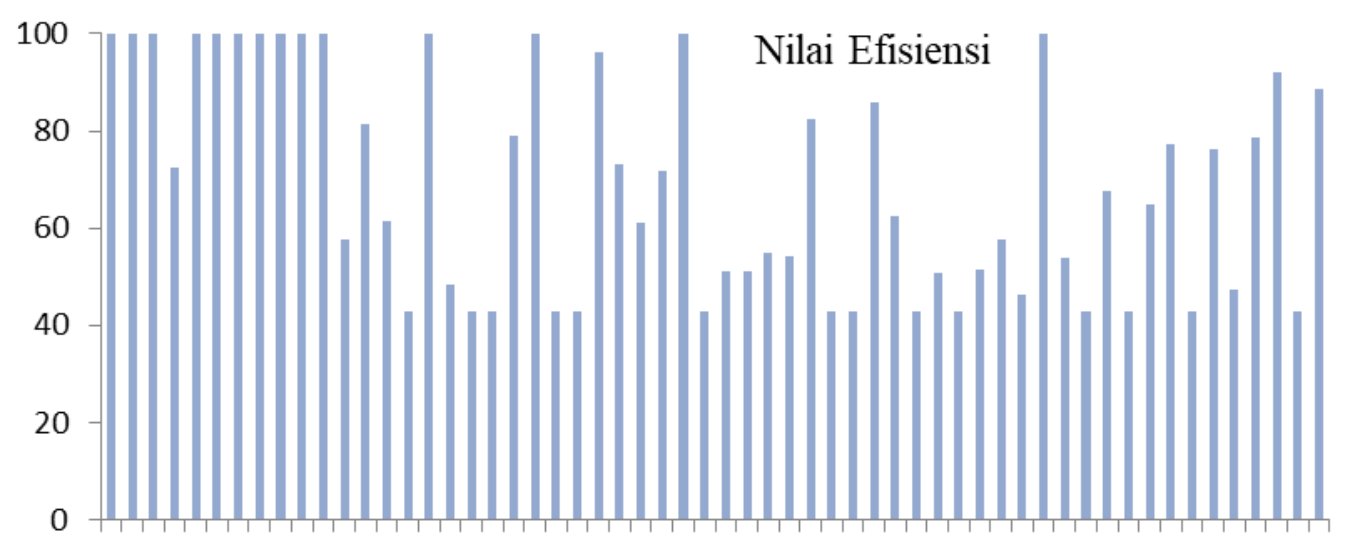

13579111315171921232527293133353739414345474951535557

Gambar 2 Distribusi nilai efisiensi pada model DEA Constant Return to Scale (CRS) untuk masing masing petani mitra pada rantai pasok gula semut di Kecamatan Kokap

Berdasarkan pengukuran kinerja petani dapat diketahui petani mitra mana saja yang harus ditingkatkan kinerjanya, melalui peningkatan output maupun meminimumkan input. Menurut Firmana (2016) petani responden yang efisien secara teknis yaitu petani yang memiliki nilai efisiensi teknis sebesar 1.000, sedangkan petani responden yang memiliki nilai efisiensi teknis kurang dari 1.000 merupakan petani yang tidak efisien secara teknis. Nilai efiisensi teknis yang diperoleh dari hasil perhitungan merupakan nilai efisiensi relatif, sehiingga tidak dapat ditarik kesimpulan secara general (umum). 
Nilai efisiensi menunjukkan bahwa seorang petani responden efisien secara relatif di lokasi penelitian terhadap petani responden lainnya pada periode tertentu.

Berdasarkna hasil perhitungan kinerja rantai pasok gula semut pada petani mitra, dapat dilihat bahwa empat belas petani mitra yang memiliki efisiensi kinerja $100 \%$ adalah petani 1,2,3,5,6,7,8,9,10,11,16,21,28 dan petani 45. Petani mitra lainnya memiliki efisinsi kinerja di bawah $100 \%$. Selain itu nilai presentase kinerja gula smeut terkecil atau ter-inefisien dimiliki petani mitra 15 dengan persentase $42.84 \%$. Potential improvoments kinerja rantai pasok petani 15 disajikan pada Tabel 17.

Tabel 1 Nilai Potential Improvement (PI) pada petani 15 pada rantai pasok gula semut di Kecamatan Kokap

\begin{tabular}{|c|c|c|c|c|}
\hline DMU & Variable & Actual & Target & $\begin{array}{c}\text { Potential } \\
\text { Improvement }(\%)\end{array}$ \\
\hline \multirow{6}{*}{$\begin{array}{l}\text { DMU } \\
15\end{array}$} & $\begin{array}{l}\text { Siklus pemenuhan } \\
\text { pesanan }\end{array}$ & 7.0 & 3.0 & 57.10 \\
\hline & Biaya rantai pasok & 13.8 & 5.8 & 57.80 \\
\hline & Cash to cash cycle time & 7.0 & 3.0 & 57.10 \\
\hline & Kinerja pengiriman & 100.0 & 100.0 & 0.0 \\
\hline & Pemenuhan pesanan & 100.0 & 100.0 & 0.0 \\
\hline & $\begin{array}{l}\text { Kesesuaian dengan } \\
\text { standar }\end{array}$ & 100.0 & 100.0 & 0.0 \\
\hline
\end{tabular}

Sumber : Hasil olahan dengan DEA

Berdasarkan hasil perhitungan potential improvements petani 15 yang memilikiefisiensi kinerja 42.84 dan yang merupakan ter-inefisien, diketahui bahwa ketidakefisienan kinerja terdapat pada tingginya nilai input yang diperoleh, sehingga perlu dilakukannya penurunan input. Nilai siklus pemenuhan pesanan yang semula 7 hari harus diturunkan menjadi 3 hari atau sebesar $57.10 \%$. Nilai biaya rantai pasok juga perlu diturunkan sebesar $57.80 \%$ dari nilai semula. Sama halnya dengan cash to cah cycle time yang harus diturunkan sebesar $57.10 \%$ dari nilai semula.

Tidak terjadi slack (kekurangan) pada output efisiensi kinerja rantai pasok. Namun sebaliknya terjadi surplus (kelebihan) pada efisiensi kinerja rantai pasok pada petani 15, yakni pada siklus pemenuhan pesanan, biaya rantai pasok, dan cash to cash cycle time, yakni masing-masing 4 hari, 8 hari dan 4 hari. Artinya petani 15 ahrus menurunkan nilai pada siklus pemenuhan pesanan, biaya rantai pasok, dan cash to cash cycle time yang dimilikinya. Untuk mengetahui reference comarison petani 15 dibandingkan petani yang sudah memiliki efisiensi kinerja $100 \%$ yakni petani 3 dapat dilihat pada Gambar di bawah ini

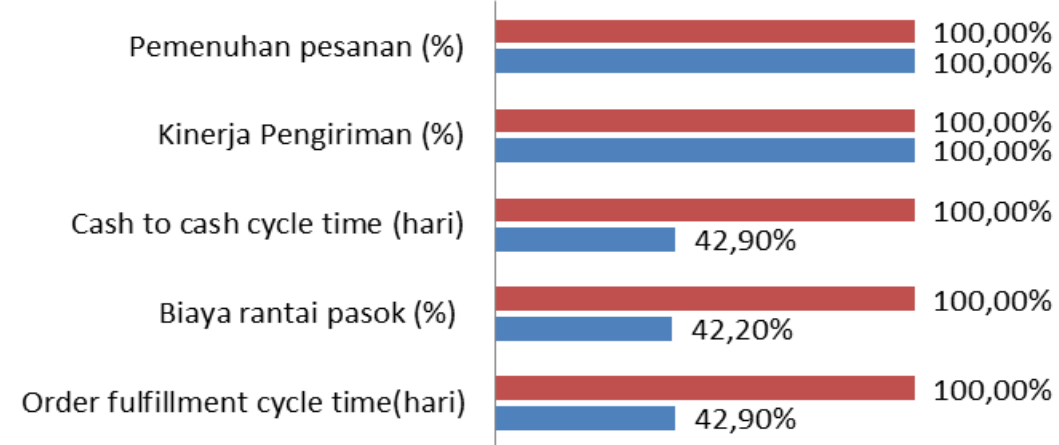

JoFSA Vol. 1, No. 2, Oktober $2017: 60-70$ 
Keterangan : Data yang ditampilkan dalam satuan \% Gambar 3 Reference comparison antara petani 15 dengan 3

Reference comparison antara petani 18 dengan petani 3 merupakan salah satu petani yang memiliki efisiensi kinerja $100 \%$ memberikan gambaran bahwa petani 18 memiliki input yang lebih tinggi dari pada petani 3. Sebaliknya petani 18 memiliki nilai output yang lebih rendah daripada nilai nilai output yang dimiliki petani 3 . Adapun nilai output yang harus paling tinggi untuk ditingkatkan adalah nilai

Efisiensi kinerja rantai pasok gula semut di tingkat petani yang kurang dari $100 \%$ dapat diatasi dengan memperbaiki kinerja rantai pasok tersebut. Caranya adalah dengan mengurangi nilai input atau memaksimalkan nilai output dengan cara menaikkannya. Adapun yang termasuk nilai nilai input adalah order fulfillment cycle time, biaya rantai pasok, dan cash to cash cycle time. Fleksibilitas rantai pasok dan persediaan rantai pasok tidak termasuk, sebab di tingkat petani kedua variabel ini tidak dapat diukur. Berdasarkan hasil perhitungan, input yang harus diturunkan terutama pada order fulfillment cycle time atau siklus pemenuhan pesanan, biaya rantai pasok dan cash to cash cycle time. Sedangkan pada output petani tersebut sudah cukup baik.

\section{Efisiensi Kinerja Rantai Pasok Gula Semut pada pengepul dan CV Menoreh Politan pada tahun 2017 dengan Metode Maksimilisasi Output}

Penukuran kinerja dilakukan pada pengepul dan CV Menoreh Politan di Kecamatan Kokap, Kabupaten Kulon Progo dengan menggunakan DEA. Pengukuran DEA berdasarkan pada faktor input dan output yang dilakukan sebelumnya, yakni berdasarkan SCOR yakni meliputi reabilitas, responsibilitas, fleksibilitas, biaya dan aset.

Tujuan dilakukannya pengukuran efisiensi pada perusahaan dan pengepul adalah mengetahui kinerja pada CV Menoreh Politan. Pengukuran dipilih untuk memaksimalisasi output. Model yang digunakan dalam pengukuran ini adalah model constant return to scale (CRS). CV Menoreh Politan dan nilai superior diukur efisiensi kinerjanya dengan menggunakan metode DEA untuk mengetahui bagaimana kinerja rantai pasok gula semut yang terjadi. Software yang digunakan untuk mengukur efisiensi kinerja gula semut ini adalah WDEA. Berdasarkan data yang diambil saat penelitian, terdapat 8 pengepul dan 1 perusahaan CV Menoreh Politan.

Tabel 2 Daftar nilai input pengukuran kinerja rantai pengepul dan perusahaan

\begin{tabular}{rccccc}
\hline & $\begin{array}{c}\text { Order } \\
\text { Fulfilment } \\
\text { (Dycle Timel } \\
\text { OFCT } \\
\text { (hari) }\end{array}$ & $\begin{array}{c}\text { Fleksibilitas } \\
\text { rantai pasok } \\
\text { (hari) }\end{array}$ & $\begin{array}{c}\text { Total Supply } \\
\text { Chain } \\
\text { Management } \\
\text { Cost (Rp/kg) }\end{array}$ & $\begin{array}{c}\text { Cash } \\
\text { to cash } \\
\text { (hari) }\end{array}$ & $\begin{array}{c}\text { Persediaan } \\
\text { harian (hari) }\end{array}$ \\
\hline X1 & $\mathrm{X} 2$ & $\mathrm{X} 3$ & $\mathrm{X} 4$ & $\mathrm{X} 5$ \\
\hline Perusahaan & 7.00 & 3.00 & - & 7.00 & 3.00 \\
Pengepul 1 & 3.00 & 0.50 & 0.00 & 7.00 & 2.00 \\
Pengepul 2 & 3.00 & 1.00 & 0.05 & 7.00 & 3.00 \\
Pengepul 3 & 3.00 & 1.00 & 0.02 & 6.00 & 2.00 \\
Pengepul 4 & 3.00 & 1.00 & 0.02 & 7.00 & 3.00 \\
Pengepul 5 & 3.00 & 0.50 & 0.01 & 7.00 & 3.00 \\
\hline
\end{tabular}




\begin{tabular}{llllll}
\hline & & & & \\
Pengepul 6 & 4.00 & 0.50 & 0.01 & 5.00 & 3.00 \\
Pengepul 7 & 3.00 & 0.50 & 0.06 & 7.00 & 3.00 \\
Pengepul 8 & 4.00 & 0.50 & 0.04 & 7.00 & 3.00 \\
\hline
\end{tabular}

Tabel 3 Daftar nilai output pengukuran kinerja rantai pengepul dan perusahaan

\begin{tabular}{cccc}
\hline $\begin{array}{c}\text { Petani } \\
(\mathrm{DMU})\end{array}$ & $\begin{array}{c}\text { Kinerja } \\
\text { Pengiriman }\end{array}$ & $\begin{array}{c}\text { Pemenuhan } \\
\text { Pesanan }\end{array}$ & Kesesuaian dengan Standar \\
\hline & $\mathrm{X} 1$ & $\mathrm{X} 2$ & $\mathrm{X} 3$ \\
\hline Perusahaan & 99.78 & 99.78 & 100.00 \\
Pengepul 1 & 100.00 & 99.57 & 99.57 \\
Pengepul 2 & 98.18 & 100.00 & 100.00 \\
Pengepul 3 & 100.00 & 99.02 & 100.00 \\
Pengepul 4 & 99.07 & 100.00 & 100.00 \\
Pengepul 5 & 100.00 & 100.00 & 100.00 \\
Pengepul 6 & 100.00 & 100.00 & 98.94 \\
Pengepul 7 & 100.00 & 100.00 & 100.00 \\
Pengepul 8 & 100.00 & 100.00 & 100.00 \\
\hline
\end{tabular}

Efisiensi kinerja rantai pasok sudah sesuai dengan harapan, dimana CV Menoreh Politan yang memiliki kinerja rantai pasok yang efisien. Waktu siklus pemenuhan pesanan pada CV Menoreh Politan hanya 3 hari karena CV Menoreh Politan sudah melakukan perencanaan dengan petani mitra, sesuai dengan kesepakatan kontraktual yang ada. Terbukti perencanaan yang dibuat oleh CV Menoreh Politan dapat mengefisiensikan waktu pemenuhan pesanan gula semut oleh distributor. CV Menoreh Politan juga memiliki persediaan harian sebesar 3 hari. Persediaan barang dan lamanya waktu gula semut berada di gudang, maka akan mengurangi kualitas produk. Namun CV Menoreh Politan selalu mempertahankan kualitas dari produknya, yaitu dengan menjaga kadar kering dari gula semut, sehingga kualitas produk CV Menoreh Politan tetap baik. CV Menoreh Politan dapat mempertahankan mitra pasarnya dengan menjaga kualitas dari produknya, sehingga kemitraan yang terjalin dapat terus berjalan.

Data yang digunakan ke program DEA berasal dari rata-rata variabel input dan output. Pengukuran kinerja dilakukan pada 8 pengepul dan empat perusahaan pengolah gula semut di Kecamatan Kokap selama satu bulan produksi. Berdasarkan hasil pengukuran kinerja rantai pasok diperoleh informasi bahwa efisiensi kinerja sembilan DMU tersebut bernilai 1, yang artinya efisien. CV Menoreh Politan menunjukkan nilai $100.00 \%$ sehingga tergolong efisien. Hasil perhitungan efisiensi kinerja rantai pasok pada pengepul dan perusahaan disajikan pada Tabel 20 berikut ini, 


$\begin{array}{lc}\text { DMU } & \text { Nilai Efisiensi Rantai Pasok (\%) } \\ \text { Perusahaan } & \mathbf{1 0 0 . 0 0} \\ \text { Pengepul 1 } & 100.00 \\ \text { Pengepul 2 } & 100.00 \\ \text { Pengepul 3 } & 100.00 \\ \text { Pengepul 4 } & 100.00 \\ \text { Pengepul 5 } & 100.00 \\ \text { Pengepul 6 } & 100.00 \\ \text { Pengepul } 7 & 100.00 \\ \text { Pengepul } 8 & 100.00\end{array}$

Kinerja perusahaan CV Menoreh Politan pada rantai pasok gula semut mencapai sempurna. Begitu juga pada sisi pengepul, kedelapan pengepul memiliki efisiensi kinerja rantai pasok $100 \%$.

\section{Pengembangan Rantai Pasok}

Usaha peningkatan kinerja rantai pasok gula semut dapat dilakukan dengan analisis kesenjangan atau GAP analysis antara kondisi kinerja rantai pasok gula semut yang terjadi saat ini dengan kondisi kinerja rantai pasok yang dijadikan acuan. Kinerja rantai pasok yang dijadikan acuan merupakan target untuk peningkatan daya saing dengan kinerja yang efisien.

Identifikasi kesenjangan antara kinerja rantai pasok gula semut yang terjadi di CV Menoreh Politan, Kulon Progo saat ini dengan kondisi rantai pasok gula semut target meliputi aspek-aspek pengukuran kinerja yang digunakan dalam analisis DEA. Aspek-aspek kinerja tersebut terdiri dari kinerja pengiriman, pemenuhan pesanan, kesesuaian dengan standar siklus peenuhan pesanan, fleksibilitas rantai pasok, biaya total rantai pasok, cash to cash cycle time serta persediaan harian.

Hasil identifikasi pengukuran kinerja rantai pasok gula semut yang membandingkan kinerja petani mitra, pengepul dan perusahaan memberikan gmbaran kondisi kinerja rantai pasok gula semut pada tingkat petani mitra saat ini menunjukkan persentase yang masih kurang maksimal. Dari 58 orang petani mitra yang menjadi sampel, hanya empat belas petani mitra yang memiliki efisiensi kinerja $100 \%$.

Hasil identifikasi kinerja rantai pasok di tingkat pengepul menunjukkan hasil yang memuaskan, dari 8 orang pengepul, tujuh diantaranya memiliki efisiensi kinerja $100 \%$. Kinerja rantai pasok gula semut di tingkat perusahaan dari 4 perusahaan gula semut, tiga diantaranya yang memiliki efisiensi kinerja rantai pasok kurang dari $100 \%$. Hal ini menandakan bahwa kinerja rantai pasok gula semut di tingkat petani maupun perusahaan belum maksimal. Belum maksimalnya kinerja rantai pasok tersebut dikarenakan nilai input yang tinggi sementara itu output yang dihasilkan rendah. Oleh karena itu perlu dilakukannya perbaikan di dalam efisiensi kinerja rantai pasok tersebut. Peningkatan kinerja di tingkat petani dapat dilakukan dengan dua cara, yakni peningkatan output atau penurunan input. Peningkatan output dapat dilakukan dengan meningkatkan nilai kinerja pengiriman, pemenuhan pesanan dan kesuaian gula semut sesuai dengan standar.

Persentase pengiriman pesanan dari petani yang tidak tepat waktu sesuai dengan pesanan yang diinginkan pelanggan perlu dilakukannya peningkatan kinerja 
pengiriman, sehingga persentase pengiriman penana dengan tepat waktu sesuai dengan keinginan konsumen. Untuk meningkatkan kinerja pengiirman rantai pasok gula semut, maka pengiriman gula semut yang dilakukan kurang dari 7 hari. Karena rata-rata petani mitra menunggu gula semut tersebut terkumpul sesuai yang dibutuhkan baru dikirim. Kondisi jalanan di daerah penelitian yang sulit juga menyebabkan pengiriman menjadi kurang lancar.

Kesesuian gula semut di tingkat petani pada kondisi saat ini belum cukup baik, kadar keringnya masih rendah, berdasarkan hal tersebut maka perlu adanya peningkatan kinerja kesesuaian gula semut dengan standar mutu yang diinginkan konsumen. Peningkatan gula semut dapat dilakukan dengan peningkatan kadar kering gula semut, melakukan proses sortasi karena ada beberapa gulasemut yang masih tercampur dengan plastik. Petani mitra juga perlu memperhatikan hygienitas dari peralatan yang dipakai seperti bumbung (tempat nira) karena akan mempengaruhi proses pengolahan agar menjadi gula semut yang baik. Karena selama ini kadang mengabaikan kebersihan peralatan tersebut. Bumbung setelah dipakai seharusnya langsung dibersihkan atauu direndam dengan air panas.

Kondisi pemenuhan pesanan saat ini yang terjadi di CV Menoreh Politan juga masih jauh pemenuhan pesanan yang diharapkan. Kinerja pemenuhan pesanan dapat meningkat dengan cara meningkatkan produktivitas gula semut atau dengan menambah mitra petani. Berbeda dengan faktor alamyang tidak dapat dikontrol akan mempengaruhi kualitas nira kelapa yaitu nira yang dihasilkan banyak namun kaulitasnya kurang bagus.

Kondisi biaya rantai pasok antar petani masih bervariasi. Penurunan biaya total rantai pasok dapat dilakukan dengan cara salah satunya adalah dengan meningatkan kuantitas untuk setiap kali pengiriman. Karena selama ini petani menunggu agar muatan kemasan penuh baru dikirim.

Siklus pemenuhan pesanan mulai dari pengadaan, pembuatan dan pengiriman saat ini sudah cukup baik, namun perlunya adanya peningkatan pada pengadaan. Peningkatan ini diharapkan dapat mencapai kondisi siklus pemenuhan pesanan gula semut sesuai dengan target. Peningkatan tersebut adalah pada pengadaan yang membutuhkan waktu cukup lama untuk pengolahannya rata-rata petani melakukannya antara satu hingga dua hari, apalagi dimusim penghujan kualitas nira yang dihasilkan kurang bagus sehingga perlu pengulangan untuk mengolah menjadi gula smeut yang bagus.

Kondisi cash to cah cycle time yang terjadi, kondisi perputaran uang perusahaan saat ini mulai dari pembayaran atau pelunasan produk oleh konsumen belum cukup baik, karena ritel masih menerapkan sistem tempo dan terkadang melebihi batas waktu pelunasan. Karena konsistensi yang terjaga akan berdampak baik bagi kondisi perusahaan dan juga kondisi keuangan petani.

\section{Simpulan dan Saran}

\section{Simpulan}

Analisis efisiensi petani dengan menggunakan Data Envelopment Analysis (DEA) diperoleh tingkat efisiensi petani. Yang telah beroperasi secara efisien yaitu sebesar 14 petani mitra CV Menoreh Politan (24.14 persen), sedangkan sisanya 44 petani mitra CV Menoreh Politan (75.86 persen) belum mencapai tingkat efisiensi yang maksimal.

JoFSA Vol. 1, No. 2, Oktober 2017: 60-70 
Ketidakefisienan petani sebagian besar disebabkan oleh biaya rantai pasok dan perputaran uang perusahaan yang terlalu lama. Untuk pengepul dan perusahaan sendiri secara keseluruhan telah beroperasi secara maksimal.

\section{Saran}

1. Petani diharapkan dapat menurunkan biaya rantai pasok dengan perusahaan memperbanyak mitra petani agar kuantitas yang didapat dapat menutupi biaya rantai pasok. Selain itu petani juga perlu mempercepat pengadaan barang, memperhatikan kualitas gula semut dengan memperhatikan hygienitas peralatan yang dipakai, dan kadar kering yang dibutuhkan.

2. Perusahaan diharapkan dapat melakukan perencanaan kolaboratif yang baik dengan ritel agar mempercepat siklus perputaran uang perusahaan sehingga perputaran uang di tingkat perusahaan dan petani lancar. Karena konsistensi yang terjaga akan berdampak baik bagi kondisi perusahaan dan juga kondisi keuangan petani.

\section{Daftar Pustaka}

Bolstorff P, Rosenbaum, R.2003. Supply Chain Excellence.A Handbook for Dramatic Improvement Using the SCOR Model.

Bolstorff P, Rosenbaum R. 2011. Supply chain excellence: a handbook for dramatic improvement using the SCOR model. New York (US): AMACOM.

[Disperindag Kulon Progo] Dinas Perindustrian dan Perdagangan, Kulon Progo 2016. Perkembengan Ekspor Komoditi Kulon Progo. Yogyakarta (ID): Dinas Perindustrian \& Perdagangan Kulon Progo.

Herawati. 2015. Kinerja dan Efisiensi Rantai Pasok Biji Kakao di Kabupaten Pasaman. Jurnal TIDP, 2(1), 43-50

Saragih, Alexandro Ephannuel. 2015. Rantai Pasok Beras di Kecamatan Cibeber, Kabupaten Cianjur. [Tesis]. Bogor (ID): Institut Pertanian Bogor

Sari, PN. 2015. Pengaruh Relationship Marketing Terhadap Kinerja Rantai Pasok Beras Organik Bersertifikat di Kabupaten Bandung Melalui Integrasi. [Tesis]. Bogor (ID): Institut Pertanian Bogor

Setiawan AS, Marimin, Arkeman Y, Udin F. 2011. Studi Peningkatan Kinerja Manajemen Rantai Pasok Sayuran Dataran Tinggi Terpilih di Jawa Barat. Agricultural Technology Journal. 31(1): 60-68.

Sustiyana, Syafrial, Purnomo M. 2013. Analisis Supply Chain Dan Efisiensi Pemasaran Gula Siwalan di Kabupaten Sumenep, Jawa Timur. (Kasus Di Kecamatan Dungkek, Kabupaten Sumenep). Habitat, 24(2): 110-119.

Tangen, S. (2004). Performance measurement : From philosophy to practice. International Journal of Productivity and Performance Management. 53(8): 726 737.

Tanjung, H. \& Devi, A. (2013). Metodologi Penelitian Ekonomi Islam. Jakarta: Gramata Publishing.

Yolandika, Clara. Analisis Supply Chain Management Brokoli di CV.Yans Fruit Vegetable Kecamatan Lembang Kabupaten Bandung Barat. [Tesis]. Bogor (w). Institut Pertanian Bogor

Zhang, H dan W. Liu dan Xiau Li. 2002. An AHP/DEA Methodology for Vendor Selection in Agile Supply Chain. Working Paper. 